\title{
KEDUDUKAN HUKUM KETETAPAN MPRS/MPR SEBELUM DAN SESUDAH PERUBAHAN UUD 1945
}

\author{
EDDY ASNAWI \\ Fakultas Hukum Universitas Lancang Kuning \\ eddyasnawi@yahoo.com
}

\begin{abstract}
Amendments to the 1945 Constitution have implications for changes in the power or institutional authority of the MPR which have consequences on the legal position of the MPRS/MPR provisions that were born, both before and after the amendment to the 1945 Constitution. For this reason, the method used is a normative juridical research method. The results of the study show that in the state administration practice as long as the 1945 Constitution is in effect before the amendments are made, the broad scope of the content that is regulated is not only limited to matters specified in the 1945 Constitution. If classified, there are MPR Decrees that meet the elements as legislation, MPR Decrees a kind of State administrative stipulation (beschikking), an MPR Decree in the form of planning $(G B H N)$, and an MPR Decree a kind of policy regulation (beliedregels) in the field of state administration. After the amendment of the 1945 Constitution was made, the legal position of the MPR Decrees became scarce. On the one hand, the amendments to the articles of the 1945 Constitution and the provision of Article 1 of the Supplementary Rules of the 1945 Constitution resulted in the loss of the MPR's authority to form MPR Decrees (types of legislation). regulate (regeling), because it no longer has a constitutional basis in the 1945 Constitution. But on the other hand with the enactment of Law Number 12 of 2011 concerning the Formation of Legislations, the legal position of the MPR Decree has come back to life as a form of legislation with the limitations as referred to in paragraph (1). in the explanation of Article 7 paragraph 1 letter $b$, namely the still valid MPRS/MPR Decrees as stipulated in MPR Decree Number 1/MPR/2003.
\end{abstract}

Keywords: Constitution, Legislation and MPR Decrees

Abstrak: Perubahan UUD 1945 membawa implikasi terhadap perubahan kekuasaan atau kewenangan kelembagaan MPR yang membawa akibat pada kedudukan hukum ketetapan MPRS/MPR yang dilahirkannya, baik itu sebelum dan sesudah perubahan UUD 1945. Kajian penelitian ini dilakukan dengan melakukan studi kepustakaan. Untuk itu metode yang digunakan adalah metode penelitian yuridis normatif. Hasil penelitian menunjukkan bahwa dalam praktik ketatanegaraan sepanjang berlakunya UUD 1945 sebelum dilakukan perubahan, cakupan luas materi muatan yang diaturnya tidak hanya terbatas pada hal-hal ditentukan dalam UUD 1945. Jika diklasifikasikan, ada Ketetapan MPR yang memenuhi unsur sebagai peraturan perundang-undangan, Ketetapan MPR sejenis penetapan administrasi Negara (beschikking), Ketetapan MPR berupa perencanaan (GBHN), dan Ketetapan MPR semacam peraturan kebijakan (beliedregels) di bidang administrasi negara. Setelah UUD 1945 dilakukan perubahan, maka kedudukan hukum Ketetapan MPR menjadi sumir, di satu sisi perubahan pasalpasal UUD 1945 dan adanya ketentuan Pasal 1 Aturan Tambahan UUD 1945 mengakibatkan hilangnya kewenangan MPR untuk membentuk Ketetapan-Ketetapan MPR (jenis peraturan perundang-undangan) bersifat mengatur (regeling), karena tidak lagi memiliki dasar konstitusioanal dalam UUD 1945. Namun di sisi lain dengan diberlakukannya UU Nomor 12 Tahun 2011 tentang Pembentukan Peraturan E-ISSN: 2657-0300 $\quad$ Lembaga Penelitian dan Penerbitan Hasil Penelitian Ensiklopedia $\quad 227$ P-ISSN: 2657-0319 
Perundang-undangan, kedudukan hukum Ketetapan MPR menjadi hidup kembali sebagai bentuk peraturan perundang-undangan dengan pembatasan sebagaimana disebut dalam penjelasan Pasal 7 ayat 1 huruf b, yakni Ketetapan-ketetapan MPRS/MPR yang masih berlaku sebagaimana ditentukan dalam Ketetapan MPR Nomor 1/MPR/2003.

Kata Kunci: Konstitusi, Peraturan Perundang-undangan dan Ketetapan MPR

\section{A. Pendahuluan}

Kedudukan hukum Ketetapan MPRS/MPR menimbulkan persoalan seiring dengan perubahan UUD 1945 sebagai konstitusi Negara. Adapun persoalan yang dimaksud yakni, bagaimana menempatkan kedudukan hukum Ketetapan MPRS/MPR dalam sistem hukum Indonesia, khususnya dikaitkan dengan hierarki dan tata urutan peraturan perundang-undangan Negara Republik Indonesia. Sehubungan dengan itu berdasarkan rumusan Pasal 1 Aturan Tambahan UUD 1945, MPR mempunyai tugas untuk melakukan peninjauan terhadap materi dan status hukum Ketetapan MPRS/MPR. Kemudian tindak lanjut dari Pasal 1 Aturan Tambahan UUD 1945, maka MPR mengeluarkan Ketetapan MPR Nomor 1/MPR/2003 tentang Peninjauan Terhadap materi dan Status Hukum Ketetapan MPR.

Sebagaimana diketahui perubahan UUD 1945 membawa implikasi terhadap perubahan kekuasaan atau kewenangan kelembagaan negara, termasuk perubahan struktur dan hal-hal lainnya terkait dengan parlemen (Fatmawati, 2009). Salah satunya adalah perubahan struktur dan kewenangan MPR yang membawa akibat pada kedudukan hukum ketetapan-ketetapan yang dilahirkannya. Dalam sejarah dan dinamika ketatanegaraan Republik Indonesia, kehadiran Ketetapan MPRS/MPR sesungguhnya sudah ada sebelum perubahan UUD 1945 dilakukan. Oleh karena itu sebagai bahan refleksi tentang kedudukan Ketetapan MPRS/MPR dalam ketatanegaraan Republik Indonesia, akan ditengahkan pula dalam uraian mengenai kedudukan Ketetapan MPRS/MPR sebelum perubahan UUD 1945 dengan maksud untuk memperkaya pemahaman dan melakukan perbandingan terhadap kedudukan Ketetapan MPRS/MPR sebelum dan sesudah perubahan UUD 1945. Harapan yang dibangun dari tulisan ini setidaknya menperjelas mengenai kedudukan hukum Ketetapan MPRS/MPR pasca perubahan UUD 1945 dilakukan.

Adapun identifikasi masalah disusun sebagai berikut: Bagaimana kedudukan MPR dalam Sistem Ketatanegaraan Republik Indonesia sesudah perubahan UUD 1945?. Bagaimana kedudukan/status hukum Ketetapan MPRS/MPR dalam sistem hukum Indonesia?.

\section{B. Metodologi Penelitian}

Kajian penelitian ini dilakukan dengan melakukan studi kepustakaan. Untuk itu metode yang digunakan adalah metode penelitian yuridis normatif. Sebagaimana dijelaskan dalam literature tentang metode penelitian, antara lain dikemukakan Soerjono Soekanto dan Sri Mamudji, bahwa penelitian hukum yang dilakukan dengan cara meneliti bahan pustaka atau data sekunder belaka dapat dinamakan penelitian hukum normatif atau penelitian kepustakaan (Soekanto, 2002). Pendapat senada dikemukakan oleh Soetandyo Wignjosoebroto, penelitian hukum yang dikatakan normatif, khusus untuk meneliti hukum sebagai norma positif (Kasim, 2002). Berangkat dari pemikiran yang dikemukakan oleh para ahli di atas, kajian dalam 
penelitian ini difokuskan pada data sekunder berupa bahan pustaka. Dari hasil kajian dicoba dianalisis, untuk kemudian ditarik beberapa kesimpulan untuk menjawab identifikasi masalah.

\section{Hasil dan Pembahasan}

\section{Kedudukan Ketetapan MPRS/MPR sebelum Perubahan UUD 1945}

Produk hukum yang dinamakan "Ketetapan MPRS/MPR " dalam sejarah ketatanegaraan sudah mulai dikenal sejak tahun 1960 (MartoSoewignjo, 1987). Kemudian baru tahun 1966 melalui Ketetapan MPRS Nomor XX/MPRS/1966 tentang Memorandum DPRGR Mengenai Sumber Tertib Hukum Republik Indonesia dan Tata Urutan Peraturan Perundang-undangan Republik Indonesia, menegaskan bahwa Ketetapan MPR disebut sebagai salah satu jenis peraturan perundang-undangan sebagaimana ditentukan dalam Ketetapan MPRS Nomor XX/MPRS/1966. Tata urutan peraturan perundang-undangan tersebut terdiri dari: 1) Undang-Undang Dasar Republik Indonesia 1945; 2) Ketetapan MPR; 3) Undang-Undang/Peraturan Pemerintah Pengganti Undang-Undang; 4) Peraturan Pemerintah; 5) Keputusan Presiden; dan 6) Peraturan-peraturan Pelaksanaan lainnya seperti: Peraturan Menteri, Instruksi Menteri, dan lain-lain.

Adapun yang melatarbelakangi lahirnya Ketetapan MPRS tersebut, adalah dimaksudkan untuk mengakhiri ekses-ekses serta penyimpangan jiwa UUD 1945 baik dalam bidang perundang-undangan maupun dalam praktik ketatanegaraan dalam kurun waktu tahun 1959-1965, dan untuk terwujudnya kepastian dan keserasian hukum, serta kesatuan tafsiran dan pengertian mengenai Pancasila dan pelaksanaan UUD 1945, maka dirasakan perlu adanya perincian dan penegasan mengenai sumber tertib hukum dan tata urutan peraturan perundang-undangan Republik Indonesia, maka dikeluarkanlah Ketetapan MPRS Nomor XX/MPRS/1966 (Soehino, 1981). Jika disimak, walaupun di dalam UUD 1945 sendiri tidak secara tegas menentukan atau menyebut nama adanya Ketetapan MPR sebagai salah satu peraturan perundangundangan, dalam hal ini UUD 1945 hanya menyebutkan 3 (tiga) macam jenis peraturan perundang-undangan, yakni Undang-undang (Pasal 5 ayat 1 jo Pasal 20 dan 21), Peraturan Pemerintah (Pasal 5 ayat 2) dan Peraturan Pemerintah Pengganti Undang-undang (Pasal 22). Namun keberadaan peraturan yang dinamakan "Ketetapan MPR" itu adalah merupakan penafsiran dari MPRS sendiri pada sidang-sidang pertamanya, yang diambil dari ketentuan Pasal 2 ayat 3: "Segala putusan Majelis Permusyawaratan Rakyat ditetapkan dengan suara yang terbanyak", dan Pasal 3: “ Majelis Permusyawaratan Rakyat menetapkan Undang-undang Dasar dan garis-garis besar daripada Haluan Negara" (Manan, 1987). Sehingga dari penafsiran ini bentuk "Ketetapan MPR" memiliki dasar hukum sebagai peraturan perundang-undangan.

Terlepas dari penafsiran tersebut di atas, patut disimak pandangan Bagir Manan, bahwa Ketetapan MPR itu juga merupakan peraturan perundang-undangan yang tumbuh dari praktik atau kebiasaan ketatanegaraan, akan tetapi pengembangannya dalam praktik berakar pada ketentuan UUD 1945, yakni mengenai wewenang MPR untuk menetapkan berbagai keputusan (Magnar, 1997). Jika diperhatikan dalam UUD 1945 hanya menyebutkan 4 (empat) hal yang memerlukan Ketetapan MPR, yakni (1) menetapkan UUD; (2) menetapkan GBHN; (3) menetapkan pengangkatan Presiden dan Wakil Presiden; dan (4) menetapkan perubahan UUD. Menurut Bagir Manan, Khusus untuk penetapan GBHN bukan termasuk peraturan perundang-undangan, akan tetapi disebut sebagai "peraturan kebijakan (beliedsregels)", yakni kebijakan negara (staatsbeleid) yang harus diikuti dalam penyelenggaraan negara untuk jangka waktu E-ISSN: 2657-0300 Lembaga Penelitian dan Penerbitan Hasil Penelitian Ensiklopedia 229 P-ISSN: 2657-0319 
tertentu dan sesudahnya harus dibuat dan ditetapkan GBHN yang baru. Begitu juga dengan Ketetapan MPR tentang pengangkatan Presiden dan Wakil Presiden bukan peraturan perundang-undangan, akan tetapi termasuk pada ketetapan yang bersifat individual dan konkrit yang disebut dengan beschikking, walaupun MPR bukan administrasi negara, akan tetapi dapat disebut sebagai beschikking dalam perspektif Hukum Administrasi Negara (Magnar, 1997). Bertitik tolak dari sini, maka tidak semua Ketetapan MPR merupakan peraturan perundang-undangan. Dengan demikian menurut Bagir Manan, kedudukan Ketetapan MPR sebagai peraturan perundangundangan menurut Ketetapan MPRS Nomor XX/MPRS/1966 harus diberi arti yang sempit, yaitu hanya ketetapan yang memenuhi kriteria peraturan perundang-undangan akan disebut peraturan perundang-undangan (Magnar, 1997).

Berdasarkan penjelasan di atas, maka berdasarkan dinamika dari praktik ketatanegaraan, memperlihatkan bahwa sebuah keputusan tertulis dari Ketetapan MPR dapat melahirkan 3 (tiga) bentuk, yakni dalam bentuk peraturan perundang-undangan (regeling); Keputusan (beschikking); dan Peraturan Kebijakan (beliedregels). Dalam pengertian lain, penerapan Ketetapan MPR tidak hanya dimaknai dalam pengertian sempit tetapi juga dalam pengertian luas yang dapat melahirkan ketiga bentuk tersebut. Apalagi dalam perkembangan praktik sebelum dilakukan perubahan UUD 1945, memperlihatkan bahwa ternyata ketetapan yang dikeluarkan MPR tidak hanya terbatas pada 4 (empat) hal yang disebut dalam UUD 1945 diatas (Magnar, 1997). Jika dikelompokkan tentang Ketetapan MPR tersebut, maka dapat ditentukan: (1) Ketetapan yang bersifat mengatur; (2) Ketetapan yang sifat materinya mengikat umum secara langsung ; (3) Ketetapan yang materinya merupakan penetapan (beschikking); dan (4) Ketetapan yang materinya mengandung pernyataan (deklarasi) (Magnar, 1997).

Perluasan cakupan Ketetapan MPR ini tampaknya didasarkan pada ketentuan Pasal 1 ayat 2 UUD 1945: "Kedaulatan adalah di tangan rakyat dan dilakukan sepenuhnya oleh Majelis Permusyawaratan Rakyat". Karena itulah maka berdasarkan Pasal 1 ayat 2 tersebut maka kekuasaan MPR sebagai penjelmaan seluruh rakyat tidaklah terbatas (limitatif) kepada hal-hal yang disebutkan tugas dan wewenangnya oleh UUD 1945 tetapi bisa meluas (enunsiatif) kepada hal-hal yang lain yang tidak disebutkan secara eksplisit (Saragih, 1978). Kedaulatan rakyat yang diartikan sebagai kekuasaan tertinggi yang mengandung kekuasaan "tanpa batas". Pemikiran semacam ini nampak pada Penjelasan Pasal 3 yang antara lain menyebutkan: "Oleh karena MPR memegang kedaulatan negara, maka kekuasaannya tidak terbatas...". Oleh karena itu putusan-putusan yang dihasilkan MPR adalah merupakan garis pokok kebijakan dalam segala bidang kehidupan negara sesuai dengan cita-cita dan asas kerohanian bangsa (Ramdlonnaning, 1983). Maka dapat dipahami pada masa itu sebelum dilakukan perubahan UUD 1945, kedudukan Ketetapan MPR sebagai produk hukum mempunyai kedudukan yang jelas dan memiliki kekuatan hukum mengikat. Tafsirnya adalah karena MPR itu merupakan pemegang kedaulatan atas nama rakyat yang konsekuensinya tugas dan wewenangnya tidak terbatas, maka tentu saja macammacam tugas dan wewenang seperti yang disebutkan UUD 1945 bukanlah ketentuan maksimal (limitatif), sebab lebih dari itu masih banyak tugas dan wewenang MPR untuk bisa ditambahkan, tergantung pada kebutuhan dan masalah yang dihadapi bangsa dan negara Indonesia (Mahfud, 1993). 


\section{Kedudukan Ketetapan MPR Sesudah Perubahan UUD 1945}

Adanya perubahan UUD 1945 yang dilakukan MPR (hasil pemilu 1999) yang disahkan perubahannya pada pada tahun 1999, 2000, 2001 dan 2002 telah melahirkan sistem ketatanegaraan baru yang berbeda dengan sebelumnya. Perubahan mendasar satu diantaranya adalah dianutnya supremasi konstitusi menggantikan supremasi MPR sebagaimana ketentuan Pasal 1 ayat 2: "Kedaulatan berada ditangan rakyat dan dilaksanakan menurut ketentuan Undang-Undang Dasar". Suatu bentuk penegasan bahwa kedudukan UUD 1945 sebagai hukum yang tertinggi yang mengatur pelaksanaan kedaulatan yang dimiliki oleh rakyat. Ihwal bahwa kedaulatan berada ditangan rakyat merupakan penegasan sistem demokrasi Indonesia yang dilaksanakan dengan segenap mekanisme yang pokok-pokok aturannya termuat di dalam UUD 1945. Dari mulai pembatasan dan distribusi kekuasaan eksekutif, legislatif dan yudikatif, termasuk juga dalam penyelenggaraan pemerintahan di daerah (Hasani, 2010).

Jadi dengan demikian, MPR tidak lagi diposisikan sebagai pelaksana sepenuhnya kedaulatan rakyat berdasarkan Pasal 1 ayat 2 sebelum perubahan UUD 1945: "Kedaulatan adalah di tangan rakyat, dan dilakukan sepenuhnya oleh Majelis Permusyawaratan Rakyat". Perubahan UUD 1945 juga tidak lagi menempatkan MPR sebagai lembaga tertinggi negara sebagai penjelmaan seluruh rakyat. Kedudukan MPR saat ini sejajar dengan lembaga negara lainnya. Moh Mahfud MD mengatakan, perubahan UUD 1945 menciptakan pola lembaga-lembaga negara dalam hubungan fungsional yang horizontal, bukan dalam hubungan struktural vertikal (Mahfud, 2008). Hal ini berimplikasi terhadap eksistensi MPR sebagai lembaga Negara, dimana MPR cenderung menjadi joint session antara anggota DPR dan anggota DPD yang memiliki fungsi bersifat lembaga konstituante yang bertugas merubah dan menetapkan UndangUndang Dasar. Secara implisit, roh atau eksistensi MPR menjadi ada atau diadakan jika berkenaan dengan kewenangan yang diberikan UUD 1945. Sebagaimana pendapat Jimly Asshidiqie yang menyatakan bahwa, organ MPR itu sendiri baru dikatakan ada (actual existence) pada saat kewenangan atau functie-nya sedang dilaksaksanakan (Asshiddiqie, 2006).

Berkaitan dengan Ketetapan MPR, setelah perubahan UUD 1945 maka tidak ada lagi Ketetapan MPR sebagai peraturan perundang-undangan. Status hukum Ketetapan MPR/S menurut Jimly Asshiddiqie yang bersifat mengatur (regeling) dianggap tidak lagi mempunyai dasar konstitusional. MPR menurut Pasal 3 juncto Pasal 8 ayat 3 UUD 1945 hanya memiliki 4 (empat) kewenangan konstitusional saja, yaitu (1) mengubah dan menetapkan UUD; (2) melantik Presiden dan/atau Wakil Presiden; (3) memberhentikan Presiden dan/atau Wakil Presiden dari jabatannya menurut UUD 1945; dan (4) memilih Presiden dan/atau Wakil Presiden untuk mengisi lowongan jabatan. Oleh karena itu, tidak ada lagi Ketetapan MPR yang bersifat pengaturan (regeling) yang boleh dibuat oleh MPR di masa datang (Asshiddiqie, 2006). MPR pasca perubahan UUD 1945 hanya diberikan kewenangan dalam membuat ketetapan yang bersifat keputusan (beschikking). Dihilangkannya kewenangan MPR untuk menetapkan GBHN, berarti aturan dasar Negara kita berlaku secara singular atau tunggal yang bertumpu kepada UUD 1945. MPR kini tidak lagi berwenang menerbitkan aturan dasar Negara (grundnorm) di luar UUD 1945 yang bersifat mengatur.

Ketentuan dalam perubahan UUD 1945 bahwa Ketetapan MPR bukan lagi merupakan peraturan perundang-undangan adalah lebih bersifat implisit. Hal ini dapat digali dan dipahami dari Pasal 24C ayat 1 dan Aturan Tambahan Pasal 1, serta adanya

E-ISSN: 2657-0300 Lembaga Penelitian dan Penerbitan Hasil Penelitian Ensiklopedia $\quad 231$


Ketetapan MPR Nomor I/MPR/2003. Pasal 24 ayat 1 menyatakan: "Mahkamah Konstitusi berwenang mengadili pada tingkat pertama dan terakhir yang putusannya bersifat final untuk menguji undang-undang terhadap Undang-Undang Dasar.....". Ketentuan ini berarti bahwa peraturan perundang-undangan yang langsung di bawah UUD adalah undang-undang. Jika masih ada Ketetapan MPR di bawah UUD, maka ketentuannya pengujiannya tentunya akan mengatur bahwa Mahkamah Konstitusi menguji Ketetapan MPR terhadap UUD dan/atau undang-undang terhadap Ketetapan MPR. Dengan demikian jelas bahwa Ketetapan MPR bukanlah peraturan perundangundangan. Kemudian Pasal 1 Aturan Tambahan UUD 1945 menentukan: "Majelis Permusyawaratan Rakyat ditugasi untuk melakukan peninjauan terhadap materi dan status hukum Ketetapan Majelis Permusyawaratan Rakyat Sementara dan Ketetapan Majelis Permusyawaratan untuk diambil putusan pada Sidang Majelis Permusyawaratan Rakyat tahun 2003". Ketentuan ini dengan jelas memerintahkan kepada MPR untuk meninjau dan menentukan status baru bagi semua Ketetapan MPR/MPRS yang sudah ditetapkan bukan lagi sebagai peraturan perundang-undangan. Aturan tambahan ini dibuat karena status Ketetapan MPR/MPRS tidak lagi peraturan perundang-undangan sehingga perlu ditentukan statusnya lebih lanjut.

Bertitik tolak dari penjelasan di atas, maka dapat dipahami ketika lahirnya UU Nomor 10 Tahun 2004 tentang Pembentukan Peraturan Perundang-Undangan, akibat tuntutan dari berbagai kalangan bahwa diperlukan pengaturan yang jelas dan tegas mengenai pembentukan peraturan perundang-undangan (Gusman, 2012), seiring menyesuaikan jenis dan pembentukan peraturan perundang-undangan dengan perubahan yang terjadi dalam UUD 1945, tidak meletakkan Ketetapan MPR sebagai salah satu jenis peraturan perundang-undangan. Dalam Pasal 7 ayat 1 UU Nomor 10 Tahun 2004 ditentukan jenis dan hirarkhi peraturan perundang-undangan yang terdiri dari: UUD 1945, UU/PERPU, PP, PERPRES dan PERDA..

\section{Ketetapan MPR Nomor 1/MPR/2003}

Beranjak dari pemikiran dengan perubahan kedudukan, tugas dan wewenang MPR menurut UUD 1945 yang dilakukan perubahan, maka mengakibatkan pula hilangnya kewenangan MPR untuk membentuk Ketetapan-Ketetapan MPR yang bersifat mengatur yang berlaku keluar, seperti membuat GBHN. Hal ini membawa pula akibat perubahan pada kedudukan dan status hukum Ketetapan MPR/MPRS dalam tata susunan peraturan perundang-undangan Republik Indonesia. Maka untuk melakukan penyesuaian terhadap perubahan tersebut dalam Sidang Tahunan MPR Tahun 2003 sebagaimana diamanatkan Pasal 1 Aturan tambahan UUD 1945, juncto Pasal I dan II Aturan Peralihan UUD 1945 yang ditetapkan oleh MPR dalam Sidang Tahunan MPR pada bulan Agustus 2002. Pasal I Aturan Tambahan menyatakan: "Majelis Permusyawaratan Rakyat ditugasi untuk melakukan peninjuan terhadap materi dan status hukum Ketetapan Majelis Permusyawaratan Rakyat Sementara dan Ketetapan Majelis Permusyawaratan Rakyat untuk diambil putusan pada Sidang Majelis Permusyawaratan Rakyat tahun 2003", sedangkan Pasal I Aturan Peralihan: "Segala peraturan perundang-undangan yang ada masih tetap berlaku selama belum diadakan yang baru menurut UUD ini". Selanjutnya Pasal II Aturan Peralihan: "Semua lembaga negara yang ada masih tetap berfungsi sepanjang untuk melaksanakan ketentuan Undang-Undang Dasar dan belum diadakan yang baru menurut UndangUndang Dasar ini”. 
Jika dicermati Ketetapan MPRS dan Ketetapan MPR yang ada dapat ditemukan beberapa jenis materi yang termuat di dalamnya sebagai berikut: 1) Ketetapan MPRS dan Ketetapan MPR yang bersifat mengatur sekaligus memberikan tugas kepada Presiden; 2) Ketetapan MPRS dan Ketetapan MPR yang bersifat penetapan (beschikking); 3) Ketetapan MPRS dan Ketetapan MPR yang bersifat mengatur kedalam (interne regelingen); 4) Ketetapan MPRS dan Ketetapan MPR yang bersifat deklaratif; 5) Ketetapan MPRS dan Ketetapan MPR yang bersifat rekomendasi; dan 6) Ketetapan MPRS dan Ketetapan MPR yang bersifat perundang-undangan. Dengan adanya perubahan kedudukan, tugas dan wewenang MPR menurut UUD 1945 yang telah diubah mengakibatkan hilangnya kewenangan MPR untuk membentuk Ketetapan-ketetapan MPR yang bersifat mengatur ke luar, seperti membuat GBHN. Karena MPR tidak lagi membuat GBHN untuk dilaksanakan oleh Presiden maka Presidenlah yang mempersiapkan program kerjanya sesuai dengan UUD 1945. Kemudian berdasarkan Pasal 6A UUD 1945 menetapkan bahwa Presiden dan Wakil Presiden dipilih dalam satu pasangan secara langsung oleh rakyat, sehingga Presiden tidak lagi mempunyai kewajiban untuk bertanggung jawab kepada MPR.

Perubahan kewenangan MPR dalam hal pembentukan Ketetapan MPR yang berlaku ke luar membawa pula akibat perubahan pada kedudukan dan status hukum Ketetapan MPRS dan Ketetapan MPR dalam tata susunan (hierarki) Peraturan Perundang-undangan. Dalam Perubahan Keempat UUD 1945 telah menegaskan bahwa perubahan UUD 1945 mulai berlaku pada tanggal ditetapkan, yakni pada tanggal 10 Agustus 2002. Namun pada saat itu masih terdapat sejumlah ketetapan MPRS dan Ketetapan MPR yang secara hukum masih berlaku.

Bertitik tolak dari itu maka MPR membentuk sebuah Ketetapan MPR Nomor 1/MPR/2003 tentang Peninjauan terhadap Materi dan Status Hukum Ketetapan Majelis Permusyawaratan Rakyat Sementara dan Ketetapan Majelis Permusyawaratan Rakyat Republik Indonesia Tahun 1960 Sampai Dengan Tahun 2002. Peninjauan ini juga sekaligus untuk memastikan bagaimana eksistensi dari Ketetapan MPR tersebut untuk saat ini dan masa yang akan datang dan untuk menghindari ketidakpastian hukum yang terjadi setelah UUD 1945 dilakukan perubahan (MPR RI, 2012). Dengan demikian, setidaknya tujuan pembentukan Ketetapan MPR ini, yakni: (1) meninjau dan menentukan hal-hal yang berhubungan dengan materi dan status hukum setiap ketetapan MPRS dan ketetapan MPR yang masih ada saat ini, serta menetapkan bagaimana keberadaan (eksistensi) dari Ketetapan MPRS dan Ketetapan MPR tersebut untuk saat ini dan masa yang akan datang, dan (2) peninjauan tersebut juga dilakukan untuk menghindari adanya ketidakpastian hukum yang akan terjadi dengan berlakunya seluruh sistem pemerintahan negara berdasarkan UUD 1945 setelah selesainya seluruh perubahan yang dilakukan oleh MPR.

Dalam Ketetapan MPR Nomor 1/MPR/2003 terdapat 139 Ketetapan MPRS dan Ketetapan MPR (1960-2002) dikelompokkan ke dalam 6 (enam) kelompok status baru, yakni: (1) dicabut dan dinyatakan tidak berlaku sebanyak 8 ketetapan; (2) dinyatakan tetap berlaku dengan ketentuan tertentu sebanyak 3 ketetapan; (3) tetap berlaku sampai dengan terbentuknya pemerintahan hasil pemilu tahun 2004 sebanyak 8 ketetapan; (4) tetap berlaku sampai dengan terbentuknya undang-undang sebanyak 11 ketetapan ; (5) masih berlaku sampai dengan ditetapkannya Peraturan Tata Tertib yang baru oleh MPR hasil pemilu 2004 sebanyak 5 ketetapan; (6) dinyatakan tidak perlu dilakukan tindakan hokum lebih lanjut, baik karena bersifat final (einmalig), telah dicabut, maupun telah selesai dilaksanakan sebanyak 104 ketetapan. Kemudian ditinjau dari sudut materi atau substansi norma hukum yang terdapat dalam Ketetapan MPRS/MPR E-ISSN: 2657-0300 Lembaga Penelitian dan Penerbitan Hasil Penelitian Ensiklopedia 233 
dapat dibedakan: (1) dari segi alamat yang dituju/diatur dapat dibedakan antara yang bersifat individual dan yang bersifat umum; (2) dari segi hal yang diatur dapat dibedakan antara yang bersifat konkrit dan abstrak; dan (3) dari segi keberlakuannya dapat dibedakan antara yang bersifat final/sekali selesai (einmalig) dan yang bersifat terus menerus (tetap berlaku dengan ketentuan).

Dari Ketetapan MPRS/MPR yang ada, sampai sekarang masih terdapat 8 (delapan) ketetapan yang dapat dikatakan masih berlaku sebagai peraturan yang mengikat untuk umum (Asshiddiqie, 2006), yakni:

1. Ketetapan MPRS Nomor XXV/MPRS/1966 tentang Pembubaran PKI. Pernyataan Sebagai Organisasi Terlarang di seluruh Wilayah RI bagi PKI dan larangan Setiap Kegiatan Untuk Menyebarkan atau Mengembangkan Faham atau Ajaran Komunis/Marxisme-Leninisme (Ketetapan ini dinyatakan tetap berlaku sebagai pedoman dalam kebijakan politik nasional, dengan ketentuan seluruh ketentuan dalam Ketetapan tersebut, ke depan diberlakukan dengan berkeadilan dan menghormati hukum, prinsip demokrasi dan HAM);

2. Ketetapan MPR Nomor XVI/MPR/1998 tentang Politik Ekonomi Dalam Rangka Demokrasi Ekonomi (Ketetapan ini berlaku sebagai pedoman politik ekonomi dalam rangka demokrasi ekonomi);

3. Ketetapan MPRS Nomor: XXIX/MPRS/1966 tentang Pengangkatan Pahlawan Ampera (Ketetapan ini berlaku hingga terbentuknya undang-undang tentang pemberian gelar, tanda jasa, dan lain-lain tanda kehormatan);

4. Ketetapan MPR Nomor XI/MPR/1998 tentang Penyelenggaran Negara yang Bersih dan Bebas Korupsi, Kolusi, dan Nepotisme. (Ketetapan ini tetap berlaku sampai terlaksananya seleuruh ketentuan dalam ketetapan tersebut);

5. Ketetapan MPR Nomor VI/MPR/2001 tentang Etika Kehidupan Berbangsa;

6. Ketetapan MPR Nomor VII/MPR/2001 tentang Visi Indonesia Masa Depan;

7. Ketetapan MPR Nomor VIII/MPR/2001 tentang Rekomendasi Arah Kebijakan Pemberantasan dan Pencegahan KKN (ketetapan ini tetap berlaku sampai terlaksananya seluruh ketentuannya);

8. Ketetapan MPR Nomor IX/MPR/2001 tentang Pembaharuan Agraria dan Pengelolaan Sumber Daya Alam. (Ketetapan ini berlaku sampai terlaksananya seluruh ketentuan dalam ketetapan tersebut).

Terkait dengan masih berlakunya Ketetapan MPR di atas, maka untuk memperjelas kedudukan hukum dari Ketetapan MPR, yang sebelumnya di dalam UU Nomor 10 Tahun 2004 tidak dinyatakan lagi sebagai bentuk peraturan perundangundangan, maka dengan lahirnya UU Nomor 12 Tahun 2011, yang menggantikan UU Nomor 10 Tahun 2004 tentang Pembentukan Peraturan Perundang-undangan, maka Ketetapan MPR dimunculkan kembali sebagai bentuk peraturan perundang-undangan. Pasal 7 ayat 1 UU Nomor 12 tahun 2011 menyebutkan: "Jenis dan hierarki Peraturan Perundang-undangan terdiri atas; (a) UUD Negara RI Tahun 1945; ((2) Ketetapan MPR; (3) UU/PERPU; (4) PP; (5) PERPRES; (6) PERDA Provinsi; dan (7) PERDA Kabupaten/Kota." Adapun Ketetapan MPR yang dimaksud dalam Pasal 7 ayat 1 adalah Ketetapan MPRS dan Ketetapan MPR yang masih berlaku sebagaimana dimaksud dalam Pasal 2 dan Pasal 4 Ketetapan MPR Nomor I/MPR/2003. 


\section{Penutup}

Kenyataan menunjukkan, bahwa dalam praktik ketatanegaraan sepanjang berlakunya UUD 1945 sebelum dilakukan perubahan, cakupan luas materi muatan yang diaturnya tidak hanya terbatas pada hal-hal ditentukan dalam UUD 1945. Jika diklasifikasikan, ada Ketetapan MPR yang memenuhi unsur sebagai peraturan perundang-undangan, Ketetapan MPR sejenis penetapan administrasi Negara (beschikking), Ketetapan MPR berupa perencanaan (GBHN), dan Ketetapan MPR semacam peraturan kebijakan (beliedregels) di bidang administrasi negara. Adapun yang dijadikan dasar memperluas cakupan materi muatan Ketetapan MPR, yakni Pasal 1 ayat 2 dan penjelasan Pasal 3 UUD 1945. Sehingga berdasarkan ketentuan dan penjelasan tersebut MPR mempunyai wewenang membuat putusan-putusan sepanjang tidak bertentangan dengan prinsip Negara berkonstitusi dan tidak ditentukan sebagai kewenangan lembaga Negara lain dalam UUD 1945. Berkaitan dengan kedudukan Ketetapan MPRS Nomor XX/MPRS/1966 ketika diberlakukan pada masa itu, ditinjau dari sistem perundang-undangan, maka ketetapan ini mengandung dua unsur penting, yakni: penentuan secara hukum keputusan-keputusan yang tergolong sebagai peraturan perundang-undangan dan penentuan secara hukum tata urutan peraturan perundangundangan. Oleh karena itu adanya putusan berupa Ketetapan MPR disebut sebagai peraturan perundang-undangan, dimana yang menjadi dasar hukumnya adalah Ketetapan MPRS Nomor XX/MPRS/1966. Dalam hal ini kedudukan Ketetapan MPR sebagai peraturan perundang-undangan menurut Ketetapan MPRS Nomor XX/MPRS/1966 harus diberi arti yang sempit, yaitu hanya ketetapan yang memenuhi kriteria peraturan perundang-undangan akan disebut peraturan perundang-undangan. Sedangkan Ketetapan MPR selain yang disebut peraturan perundang-undangan, harus dipandang sebagai kaidah-kaidah yang tumbuh dari dan sebagai praktik atau kebiasaan ketatanegaraan yang dapat dijadikan sebagai sumber sistem Peraturan Perundangundangan. Setelah UUD 1945 dilakukan perubahan, maka kedudukan hukum Ketetapan MPR menjadi sumir, di satu sisi perubahan pasal-pasal UUD 1945 dan adanya ketentuan Pasal 1 Aturan Tambahan UUD 1945 mengakibatkan hilangnya kewenangan MPR untuk membentuk Ketetapan-Ketetapan MPR (jenis peraturan perundang-undangan) bersifat mengatur (regeling), karena tidak lagi memiliki dasar konstitusioanal dalam UUD 1945. Namun di sisi lain dengan diberlakukannya UU Nomor 12 Tahun 2011 tentang Pembentukan Peraturan Perundang-undangan, kedudukan hukum Ketetapan MPR menjadi hidup kembali sebagai bentuk peraturan perundang-undangan dengan pembatasan sebagaimana disebut dalam penjelasan Pasal 7 ayat 1 huruf b, yakni Ketetapan-ketetapan MPRS/MPR yang masih berlaku sebagaimana ditentukan dalam Ketetapan MPR Nomor 1/MPR/2003. Sehubungan dalam kerangka mendudukkan kembali Ketetapan MPR menyangkut eksistensi dan menghindari ketidak kepastian hukumya, maka keberadaan MPR pada masa kini harus diperluas kedudukannya dalam pelaksanaan tugas dan kewenangannya berdasarkan sila keempat dari Pancasila "Kerakyatan yang dipimpin oleh hikmah kebijaksanaan dalam permusyawaran/perwakilan”. Sehingga Ketetapan yang dilahirkan MPR tidak hanya terbatas ketentuan UUD 1945 akan tetapi lebih dari itu. Dengan demikian Ketetapan-Ketetapan yang dibuat MPR merupakan pengewajatahan dari sila keempat Pancasila. Dalam tataran peraturan perundang-undangan, ketentuan UU Nomor 12 Tahun 2011 di dalam Pasal 7 ayat 1 beserta penjelasannya berkaitan dengan Ketetapan MPR, tidak hanya sebatas Ketetapan MPR yang masih berlaku berdasarkan Ketetapan MPR Nomor I/MPR/2003, akan tetapi juga Ketetapan MPR yang kemudian tumbuh dan berkembang dalam praktik ketatanegaraan sebagai bentuk palaksanaan sila E-ISSN: 2657-0300 Lembaga Penelitian dan Penerbitan Hasil Penelitian Ensiklopedia 235 
keempat Pancasila. Karena bagaimanapun juga tidak ada sistem ketatanegaraan di negara manapun yang tidak dilengkapi oleh kaidah-kaidah yang tumbuh dari dan sebagai praktik atau kebiasaan ketatanegaraan yang dapat dijadikan sebagai sumber sistem Peraturan Perundang-undangannya.

\section{Daftar Pustaka}

Bagir Manan, Kuntana Magnar, Peranan Peraturan Perundang-undangan Dalam Pembinaan Hukum Nasional, Bandung: Armico, 1987.

Bagir Manan, Kuntana magnar, Beberapa Masalah Hukum Tata Negara Indonesia, Bandung: Alumni, 1997.

Ifdhal Kasim, 70 Tahun Prof Soetandyo Wignjosoebroto, Hukum Paradigma, Metode dan Dinamika Masalahnya, Jakarta: Elsam-Huma, 2002.

Jimly Asshiddiqie, Sengketa Kewenangan Konstitusional Lembaga Negara, Jakarta: Konstitusi Pers, 2006.

Jimly Asshiddiqie, Pengantar Ilmu Hukum Tata Negara, Jakarta: Konstitusi Press, Jakarta, 2006.

Moh.Kusnardi, Bintan R. Saragih, Susunan Pembagian Kekuasaan Negara Menurut Sistem Undang-Undang Dasar 1945, Jakarta: Gramedia, 1978.

Moh.Mahfud MD, Dasar dan Struktur Ketatanegaraan Indonesia, Yogyakarta: UII Press, 1993.

Moh. Mahfud MD, "Perubahan UUD 1945 dan Perkembangan Hukum Tata Negara", Bahan Ceramah Umum Pada Rakernas Asosiasi Pengajar HTN-HAN SeIndonesia, Jakarta, 5 Desember 2008.

MPR RI, Panduan Pemasyarakatan UUD Negara Republik Indonesia Tahun 1945 dan Ketetapan MPR Republik Indonesia, Jakarta: Sekretariat Negara, 2012.

Ramdlonnaning, Cita dan Citra Hak-Hak Azasi Manusia di Indonesia, Jakarta:Lembaga Kriminologi UI, 1983.

Soerjono Soekanto, Sri Mamudji, Penelitian Hukum Normatif Suatu Tinjauan Singkat, Jakarta: Rajawali Pres, 1990

Soehino, Hukum Tata Negara Teknik Perundang-Undangan, Yogyakarta: Liberty, 1981.

Sri Soemantri MartoSoewignjo, "Undang-Undang Dasar dan Ketetapan Majelis Permusyawaratan Rakyat Sebagai Produk Majelis Permusyawaratan Rakyat", Makalah Pidato Pengukuhan Guru Besar Tetap Fakultas Hukum Universitas Padjadjaran, Bandung, 21 Februari 1987.

Delfina Gusman, "Kedudukan Peraturan Pemerintah Pengganti Undang-Undang (PERPU) Dalam Sistem Ketatanegaraan Indonesia”, Jurnal Hukum R espublica, Fakultas Hukum Universitas Lancang Kuning, Vol. 12 Nomor 1, November 2012.

Ismail Hasani, "Erosi Konstitusionalisme: Tinjauan Politik dan Hukum Perda-Perda Diskriminatif Dalam Kerangka Konstitusi”, Jurnal Dignitas, Elsam, Volume VI Nomor 1 Tahun 2010.

Fatmawati, "Catatan Singat Mengenai Kedudukan MPR Sesudah Perubahan UUD 1945", Jurnal Hukum dan Pembangunan, Fakultas Hukum Universitas Indonesia, Tahun ke 39 Nomor 4, Oktober 2009. 